\title{
First Experience Using Navigation-Guided Radiofrequency Kyphoplasty for Sacroplasty in Sacral Insufficiency Fractures
}

\section{Erste Ergebnisse der navigationsgestützten Radiofrequenz- Kyphoplastie für die Sakroplastie bei sakralen Insuffizienzfrakturen}

Authors

Affiliation
J.-H. Klingler, P. Kluge, R. Sircar, E. Kogias, C. Scholz, M. T. Krüger, C. Scheiwe, U. Hubbe

Department of Neurosurgery, Freiburg University Medical Center, Freiburg

Key words
spine
navigation
osteoporosis
sacroplasty
sacral insufficiency fracture
radiofrequency kyphoplasty

eingereicht 31.12 .2012 akzeptiert 21.4 .2013

Bibliography

DOI http://dx.doi.org/

$10.1055 / \mathrm{s}-0033-1335582$

Published online: 25.6.2013

Fortschr Röntgenstr 2013; 185:

733-740 @ Georg Thieme

Verlag KG Stuttgart · New York . ISSN 1438-9029

\section{Correspondence \\ Dr. Jan-Helge Klingler \\ Department of Neurosurgery, Freiburg University Medical \\ Center \\ Breisacher Str. 64 \\ D-79106 Freiburg \\ Germany \\ Tel.: + +49/7 61/27050010 \\ Fax: + +4 9/7 61/27050240 \\ jan-helge.klingler@uniklinik- \\ freiburg.de}

\section{Zusammenfassung \\ $\nabla$}

Ziel: Bewertung der Wirksamkeit und Sicherheit der Sakroplastie mittels navigationsgestützter Radiofrequenz-Kyphoplastie für sakrale Insuffizienzfrakturen.

Methoden: Die monozentrische retrospektive Beobachtungsstudie umfasst vier konsekutive Patienten mit sakralen Insuffizienzfrakturen, welche zwischen April 2010 und Mai 2012 mittels Sakroplastie unter Verwendung der navigationsgestützten Radiofrequenz-Kyphoplastie behandelt wurden. Erfasst wurden die Symptomatik, Schmerzdauer sowie -intensität und Zementextravasationen in triplanar rekonstruierten CTScans des Os sacrum.

Ergebnisse: Alle Patienten berichteten eine deutliche Schmerzreduktion von präoperativ VAS 8,3 $\pm 0,5$ auf $2,3 \pm 1,0(\mathrm{p}<0,001)$ am ersten postoperativen Tag bzw. auf $1,3 \pm 1,9(\mathrm{p}<0,004)$ zum Zeitpunkt der Nachuntersuchung (durchschnittlich 20,1 Wochen). Leichtgradige Zementextravasationen traten auf, jedoch ohne Anhalt für eine Schmerzverursachung. Ferner traten keine Komplikationen oder interventionsbezogene Morbiditäten auf.

Schlussfolgerungen: Von der limitierten Erfahrung von vier Patienten scheint die navigationsgestützte Radiofrequenz-Kyphoplastie eine sichere und wirksame Behandlungsoption für sakrale Insuffizienzfrakturen darzustellen, wenngleich asymptomatische Zementextravasationen auftraten. Die auf intraoperative Bildgebung basierende 3D-Navigation vereinfacht die Positionierung der navigierten Zugangsnadeln über den long-axis Zugang. Die Radiofrequenz-Kyphoplastie bietet die Möglichkeit, eine ausreichende Menge Knochenzement mit konstanter Viskosität über die Zeit des gesamten Eingriffes und somit mit hoher Sicherheit und geringen Zementextravasationen einzubringen. Die Sakroplastie ermöglicht durch die rasche und dauerhafte Schmerzlinderung eine schnelle Mobilisierung der Patienten.

\section{Abstract \\ $\nabla$}

Purpose: To evaluate the efficacy and safety of navigation-guided radiofrequency kyphoplasty for sacroplasty in patients with sacral insufficiency fractures.

Methods: In this single-center retrospective observational study, four consecutive patients with sacral insufficiency fractures were treated with navigation-guided radiofrequency kyphoplasty for sacroplasty between April 2010 and May 2012. Symptom characteristics, pain duration and pain intensity were recorded for each patient. Cement extravasation was evaluated in thin-sliced and triplanar reconstructed CT scans of the sacrum.

Results: Four female patients with painful sacral insufficiency fractures and extensive osteopenic areas significantly improved from an average pre-treatment VAS score of $8.3 \pm 0.5$ to $2.3 \pm 1.0$ $(\mathrm{p}<0.001)$ on the first postoperative day and to $1.3 \pm 1.9(p<0.004)$ at follow-up (mean, 20.1 weeks). Slight cement extravasations were observed without evidence of being symptomatic. No major complications or procedure-related morbidity were noted.

Conclusion: From the limited experience in four patients, navigation-guided radiofrequency kyphoplasty appears to be a safe and effective treatment option for sacral insufficiency fractures even though asymptomatic cement extravasation was noted. The use of navigation based on intraoperative $3 \mathrm{D}$ images simplifies the positioning of the navigated bone needles via the long axis approach. The radiofrequency kyphoplasty system provides the possibility to administer a sufficient amount of bone cement with a well-defined viscosity over the entire period of the procedure leading to high security and low cement extravasation. Sacroplasty provides rapid and enduring pain relief and facilitates prompt mobilization. 


\section{Introduction}

$\nabla$

Sacral insufficiency fractures (SIFs) are a subtype of stress fracture of the sacrum usually affecting elderly women with osteoporosis [1 - 3]. Patients with SIFs have nonspecific low back pain that may radiate to the buttock, hip, or groin. Moreover, they typically present with tenderness to palpation in the sacral and lower back region [4-6]. Since these symptoms are rather diffuse, the diagnosis and treatment of SIFs are usually delayed. The most sensitive imaging techniques to detect SIFs are STIR (short tau inversion recovery) sequence MRI and bone scintigraphy [6]. After diagnosis, the standard treatment regimen for SIFs has usually been conservative care and comprises bed rest, rehabilitation, and analgesics [7]. Conservative treatment, however, results in relatively slow relief of symptoms and varies between 6 and 15 months $[5,6,8]$. The associated long-term immobilization and bed rest carry the risk of deep vein thrombosis, pulmonary embolism, loss of muscle mass, pneumonia, impaired cardiac function, decubitus, ulceration, and bone demineralization, predominantly in the elderly $[6,9,10]$. Therefore, sacroplasty has become increasingly popular as an alternative to conservative treatment for faster relief of symptoms, earlier mobilization and hence the regaining of quality of life. Sacroplasty is a minimally invasive technique for injecting bone cement into the fractured sacrum similar to vertebroplasty in fractured vertebral bodies. Previous studies indicate that sacroplasty is a safe and effective procedure providing early pain relief in patients with SIFs, but validation in randomized controlled trials is still unavailable $[3,6,11-22]$.

One surgically relevant feature of an osteoporotic SIF in comparison to vertebral body fractures is the much larger osteopenic area. In this respect, high viscosity cement with a constant viscosity throughout the whole procedure might be advantageous to fill these extensively modified bone structures and prevent cement extravasation to the greatest extent possible. The StabiliT Vertebral Augmentation System (DFine Europe, Mannheim, Germany) is supposed to provide ultra high viscosity cement with a processing time of approximately 30 minutes via radiofrequency kyphoplasty [23]. Radiofrequency kyphoplasty has already been used for osteoporotic vertebral body fractures with good results $[21,24]$. The characteristics of radiofrequency kyphoplasty might represent an improvement in augmentation techniques, especially for sacroplasty where larger areas have to be augmented on both sides of the sacrum and a well-defined viscosity of the cement throughout the whole procedure might be beneficial. However, reports on the use of radiofrequency kyphoplasty in sacroplasty have not been available until now.

The second essential feature the surgeon encounters during sacroplasty is the special anatomy of the sacral alae, which in most cases are the location of the fracture lines lateral to the neural foramen. Using solely fluoroscopy, only vertebral bodies S1 to S5 are apparent in the lateral plane, whereas the contours of the alae are not delineable and do not match the contours of the vertebral bodies at all ( $\bullet$ Fig. 1). Demanding additional anatomical information, intraoperative 3-dimensional (3D) imaging combined with navigation should lead to a more convenient and precise orientation.

This article describes the first experience with navigation-guided radiofrequency kyphoplasty in performing sacroplasty in four patients with bilateral SIFs and extensive osteopenic areas.

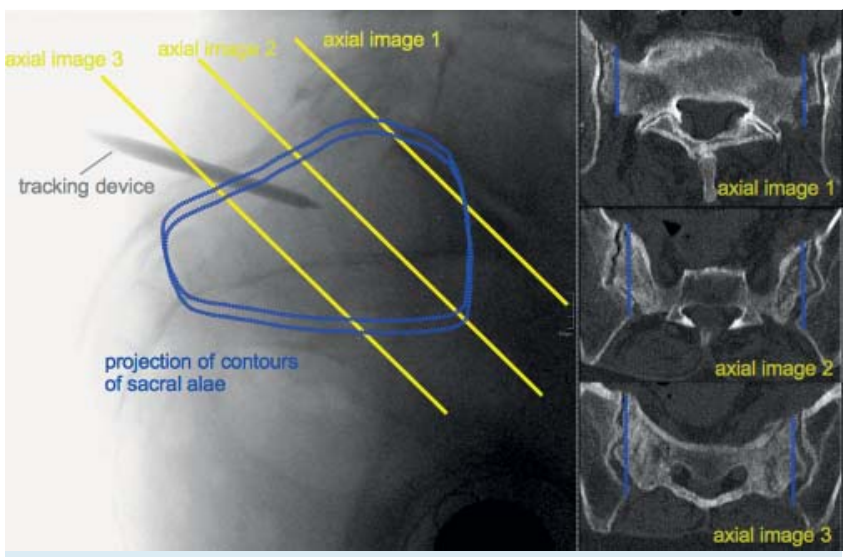

Fig. 1 Anatomical characteristics of the sacrum. Left side: Lateral fluoroscopic image of the sacrum. Note the superimposed contours of the sacral alae (blue dotted lines) not detectable in the image and not matching the contours of the sacral vertebral bodies. Right side: Axial CT images of the sacrum corresponding to the yellow lines on the left side. The blue dotted lines display the extent of the sacral alae likewise superimposed on the left side.

Abb. 1 Anatomische Besonderheiten des Os sacrum. Links: Fluoroskopie (seitlicher Strahlengang) des Os sacrum. Die eingezeichneten Konturen der Alae ossis sacri (blaue gepunktete Linien) sind im Röntgenbild nicht detektierbar und entsprechen nicht der Kontur der sakralen Wirbelkörper. Rechts: Axiale CT-Bilder des Os sacrum in Höhe der gelben Linien auf der linken Seite. Die blauen gepunkteten Linien zeigen die Ausdehnung der Alae ossis sacri auf, welche ebenso auf der linken Seite dargestellt werden.

\section{Methods}

$\nabla$

\section{Patient selection}

A single-center retrospective study was conducted with consecutive patients who underwent sacroplasty for SIFs between April 2010 and May 2012. All patients had to meet the following inclusion criteria:

- severe sacral pain refractory to conservative medical management for a minimum of six weeks (VAS score $>7$ ),

- loss of self-supply due to immobilizing pain,

- imaging evidence (MRI, CT) of SIFs ( $\bullet$ Fig. 2 ).

Patients with tumorous destruction or infectious disease of the sacrum were excluded from the study.

The local ethics committee approved the study. Informed consent was obtained from all patients.

\section{Procedure}

All patients underwent sacroplasty via the long-axis approach [26] under general anesthesia. Patients were placed in a prone position. A navigation tracker was mounted on the iliac crest, and an intraoperative 3D fluoroscopy-based CT scan of the sacrum was acquired using a 3D flat-panel C-arm (Vision FD Vario 3D, Ziehm Imaging, Nuremberg, Germany), automatically transferred to the navigation system (Cart II System with SpineMap 3D Navigation, Stryker, Freiburg, Germany) and automatically registered with an accuracy below $0.5 \mathrm{~mm}$. An instrument tracker was mounted on the bone needles (10-gauge). After calibration, the navigated bone needles were successively placed bilaterally along the longitudinal extent of the sacral alae perforating S3-S1 under image-guided navigation without the use of further fluoroscopy ( Fig.3). After navigation-guided insertion of the bone needles, StabiliT ER ${ }^{2}$ bone cement (DFine) was gradually in- 


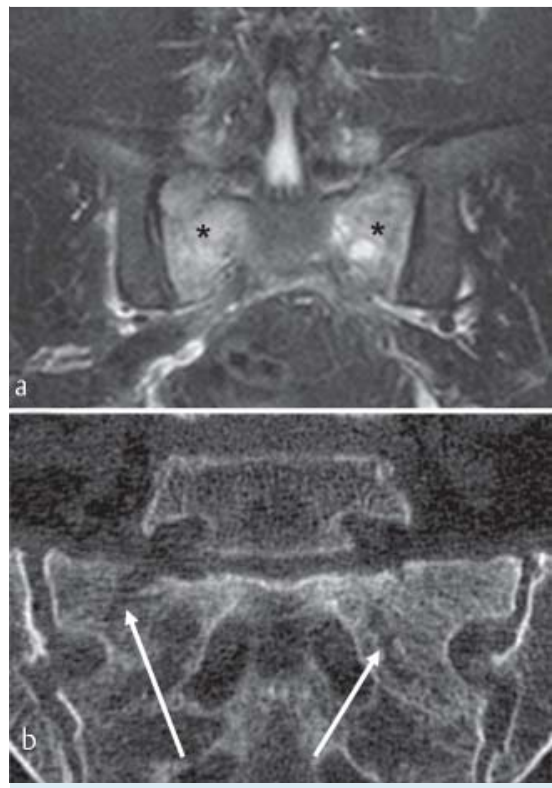

Fig. 2 Preoperative imaging (Patient 1). Coronal oblique T2-weighted MRI a demonstrating bilateral edema of the sacral alae (asterisks) related to SIFs. CT scan b showing extensive osteopenic areas of the sacrum with bilateral SIFs (arrows) in zone 1 according to the classification system proposed by Denis et al. [25], which is defined lateral to the neural foramina and medial to the sacroiliac joints. SIF - sacral insufficiency fracture.

Abb. 2 Präoperative Bildgebung (Patient 1). Das koronare T2 gewichtete MRT a zeigt bilaterale Ödeme der Alae ossis sacri (Sterne), welche den SIF entsprechen. Das CT b zeigt ausgedehnte osteopenische Gebiete des Os sacrum mit bilateralen SIF (Pfeile) entsprechend der Zone 1 nach der Klassifikation von Denis et al. [25], welche lateral der Neuroforamina und medial der Iliosakralgelenke definiert ist. SIF - sakrale Insuffizienzfraktur.

jected on each side along the fracture lines using radiofrequency kyphoplasty under fluoroscopic surveillance by sequentially withdrawing the bone needle ( $\bullet$ Fig. 4 ) until adequate cement distribution was achieved. If cement extravasation was observed, cement instillation was stopped and, if required, continued after the bone needle had been positioned in a new distant location (o Fig. 4b, c).

The radiofrequency kyphoplasty system contains a radiofrequency generator, hydraulic delivery system and activation element (cement heating cartridge component) converting the StabiliT $\mathrm{ER}^{2}$ bone cement to a very high viscous material immediately after passing through the activation element. Additionally, the activated StabiliT ER ${ }^{2}$ bone cement maintains its semi-solid viscosity over an extended working time of approximately $30 \mathrm{~min}$ utes and, hence, can be used for multiple intermittent deliveries at different sites [23,27].

All patients had bilateral SIFs and both sides were treated with navigation-guided radiofrequency kyphoplasty for sacroplasty. One of these patients concomitantly underwent minimally invasive neurolysis of the left L5 nerve root due to stenosis of the neural foramen $\mathrm{L} 5 / \mathrm{S} 1$.

\section{Data collection}

For each patient we collected demographic data, symptom characteristics, type of imaging studies, significant comorbidities, pain duration as well as pain intensity on the visual analog scale (VAS) preoperatively, on the first postoperative day and at follow-
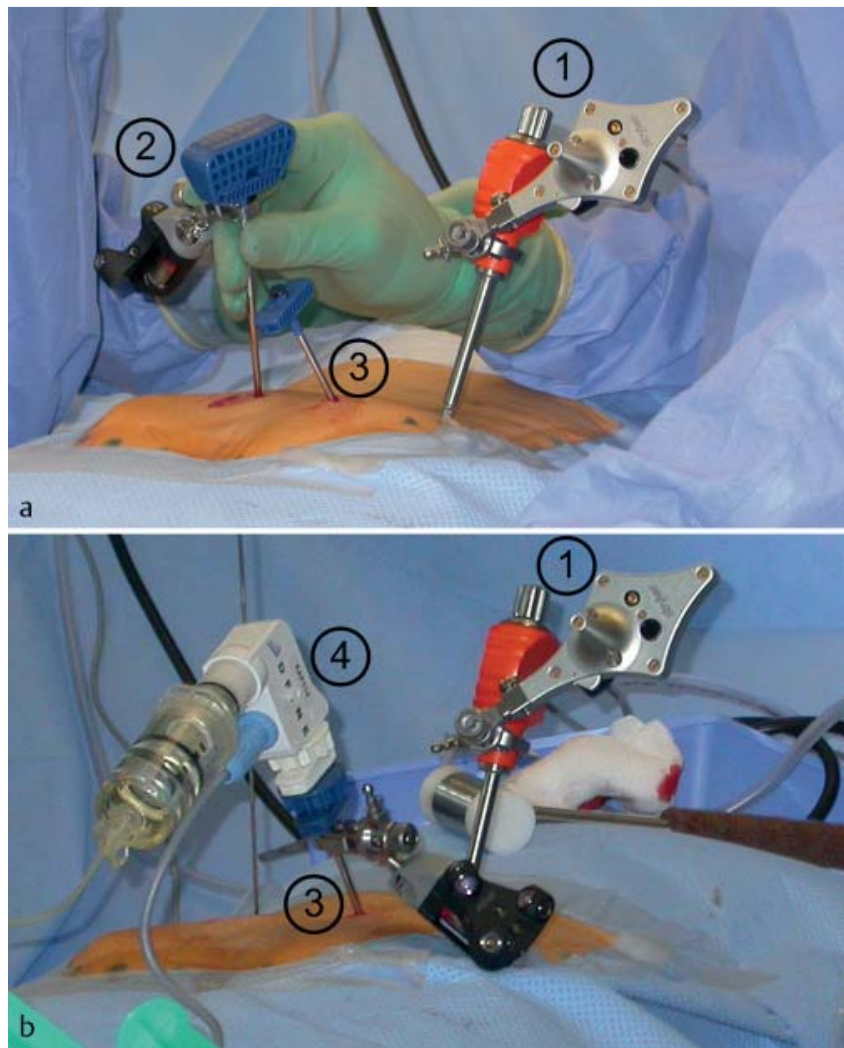

Fig. 3 Intraoperative setting. a A 10-gauge Jamshidi needle (orange, 1) with a navigation tracker (silver, 1 ) was mounted on the right iliac crest. After acquisition of an intraoperative 3D fluoroscopy-based CT scan of the sacrum, the bone needle (blue, 2) with a second navigation tracker (black, 2) was inserted under 3D image-guided navigation along the longitudinal extent of the left sacral ala. Another bone needle has already been placed on the right side (3). b The radiofrequency bone cement application system (4) is mounted on the right bone needle (3) that has been again equipped with a navigation tracker (black) to guarantee convenient adjustments of the bone needle in the sacral ala under image-guided navigation during bone cement instillation. Bone cement instillation was performed under simultaneous fluoroscopic surveillance (example given in ( Fig. 4).

Abb.3 Intraoperative Darstellung. a Eine 10-Gauge Jamshidi-Nadel (orange, 1) wurde mit einem Navigationstracker versehen an der rechten Crista iliaca befestigt. Nach der Anfertigung eines intraoperativen 3DFluoroskopie-basierten CT des Os sacrum wurde eine Zugangsnadel (blau, 2) mit einem zweiten Navigationstracker (schwarz, 2) unter bildgestützter 3D-Navigation entsprechend des long-axis Zugangs durch die linke Ala ossis sacri eingebracht. Eine weitere Zugangsnadel wurde bereits auf der rechten Seite eingebracht (3). b Das Radiofrequenz-Kyphoplastie-Applikationssystem (4) wurde auf die rechte Zugangsnadel (3) montiert, welche ihrerseits wiederum mit einem Navigationstracker versehen wurde (schwarz), um während der Knochenzementeinspritzung gezielte Neupositionierungen der Zugangsnadel in der Ala ossis sacri unter bildgestützer Navigation zu gewährleisten. Die Knochenzementeinspritzung erfolgte unter gleichzeitiger fluoroskopischer Überwachung (siehe $\bullet$ Fig. 4).

up. Furthermore, neurological examinations were performed by spine neurosurgeons at each visit.

Postoperative thin-sliced and triplanar reconstructed CT scans were available in all patients to evaluate cement extravasation.

\section{Statistical analysis}

Results were expressed as mean values with standard deviations. Analysis of independent continuous quantitative variables (VAS 


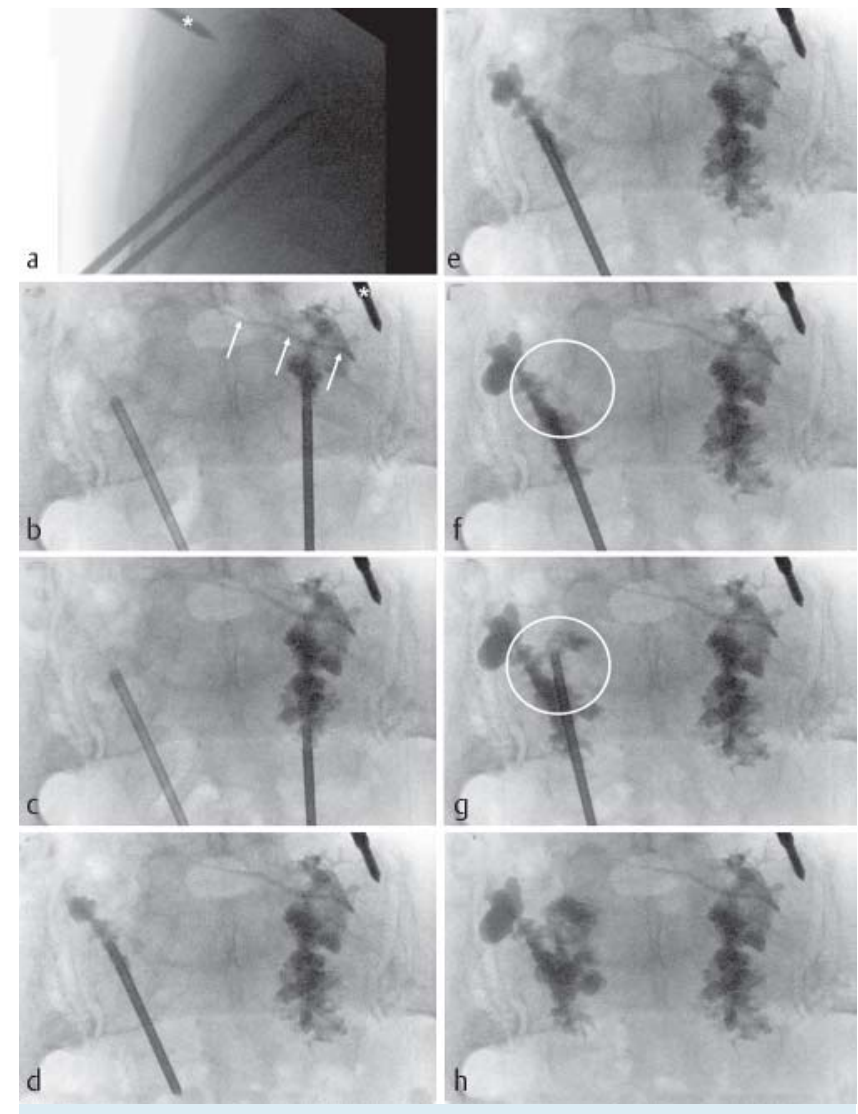

Fig. 4 Intraoperative fluoroscopy (Patient 1). Lateral fluoroscopy a showing the bilaterally introduced bone needles along the longitudinal extent of the sacral alae perforating S3-S1, according to the long-axis approach. Asterisks depict the navigation tracker mounted on the left iliac crest $\mathbf{a}, \mathbf{b}$. Anterior-posterior fluoroscopies $\mathbf{b}-\mathbf{h}$ showing sequential injection of StabiliT ER ${ }^{2}$ bone cement into the left $\mathbf{b}-\mathbf{d}$ and right $\mathbf{d}-\mathbf{h}$ sacral alae. Immediately after detection of cement extravasation into a presacral vein (b, arrows), the bone needle was retracted and cement instillation was continued more caudally $\mathbf{c}$ preventing a progression of cement extravasation. Notice that the right bone needle was moved under navigation guidance for delivering bone cement more medially (encircled in $\mathbf{f}-\mathbf{g}$ ).

Abb.4 Intraoperative Fluoroskopie (Patient 1). Im seitlichen Strahlengang a sind die bilateral eingebrachten Zugangsnadeln entsprechend des long-axis Zugangs durch die Alae ossis sacri in Höhe SWK-3 bis SWK-1 abgebildet. Sterne kennzeichnen den Navigationstracker, der an der linken Crista iliaca angebracht wurde a, b. Im anterior-posterioren Strahlengang b-h sind die schrittweisen Injektionen des StabiliT ER ${ }^{2}$ Knochenzementes in die linke $\mathbf{b}-\mathbf{d}$ bzw. rechte $\mathbf{d}-\mathbf{h}$ Ala ossis sacri abgebildet. Unmittelbar nach der Detektion einer Zementextravasation in eine präsakrale Vene (b, Pfeile) wurde die Zugangsnadel zurück gezogen. Die Knochenzementeinspritzung wurde daraufhin weiter kaudal fortgeführt c, um eine weitere Zementextravasation zu verhindern. Anzumerken ist die navigationsgestützte Neupositionierung der rechten Zugangsnadel, um Knochenzement weiter medial zu applizieren (eingekreist in $\mathbf{f}-\mathbf{g}$ ).

scores) was performed using the two-tailed Student's t-test in Microsoft ${ }^{\circledR}$ Excel $^{\circledR}$ for Mac 2011. P-values $<0.05$ were considered to be statistically significant.

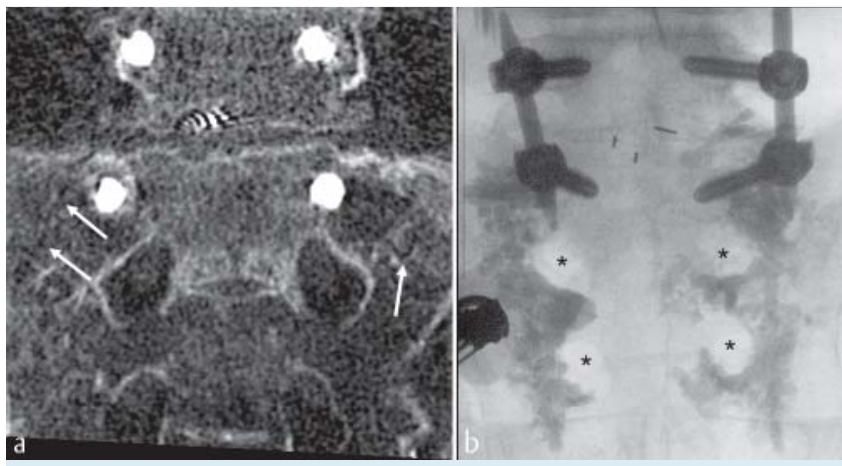

Fig. 5 Preoperative and postoperative imaging (Patient 2). Preoperative coronal oblique CT scan a demonstrating SIFs (arrows) with large osteopenic areas in the sacral alae. Final intraoperative fluoroscopy $\mathbf{b}$ showing the cement distribution in the sacral alae respecting the neural foramina (asterisks). Moreover, the spondylodesis with an intervertebral TLIF cage is shown at L5/S1. SIF - sacral insufficiency fracture, TLIF - transforaminal lumbar interbody fusion

Abb.5 Präoperative und postoperative Bildgebung (Patient 2). Das präoperative koronare CT a zeigt SIF (Pfeile) mit ausgedehnten osteopenischen Gebieten im Bereich der Alae ossis sacri. Die abschließende intraoperative Fluoroskopie b zeigt die Zementverteilung in den Alae ossis sacri ohne Übertritt in die Neuroforamina (Sterne). Daneben stellt sich eine Spondylodese mit einem intervertebralen TLIF Cage in Höhe LWK-5/SWK-1 dar. SIF sakrale Insuffizienzfraktur, TLIF - transforaminale lumbale interkorporelle Fusion.

\section{Results}

$\nabla$

\section{Demographics}

All four patients were female with a mean age of $73 \pm 8$ years. Three of them were obese with a body mass index of more than $30 \mathrm{~kg} / \mathrm{m}^{2}$ and had been under anti-osteoporotic therapy due to previously known osteoporosis ( 0 Tab. 1 ). The fourth patient had a normal body mass index and suffered from rheumatoid arthritis with multiple joint affections.

\section{Clinical outcome}

There were no procedure-related neurological deficits, hemorrhages, infections, pulmonary emboli or deaths. Patients were mobilized on the first postoperative day and reported substantial and statistically significant relief of the preoperative pain from an average VAS score of $8.3 \pm 0.5$ to $2.3 \pm 1.0$ ( $\mathrm{p}<0.001$ ) ( $\bullet$ Tab. 2 ). After a mean follow-up of 20.1 weeks, the pain level further ameliorated to $1.3 \pm 1.9$ ( $\mathrm{p}<0.004$ vs. preoperatively).

\section{Radiological outcome}

Thin-sliced and triplanar reconstructed CT scans showed the applied bone cement in both sacral alae around the neural foramina in all patients ( $\bullet$ Fig. 5-7). Slight cement extravasations through the superior margin of the sacral ala were present in patient 1 and $2(\bullet$ Fig. $3,5,7$ ). In patient 3 ( $\bullet$ Fig. 6 ) and 4 , slight cement extravasation into the right neural foramen of S2 was detected. None of the cement extravasations was symptomatic.

\section{Discussion \\ V}

\section{Clinical outcome}

Previous reports have already demonstrated that sacroplasty provides prompt relief of pain in patients with SIFs $[7,11,13,16$, 


\begin{tabular}{|c|c|c|c|c|c|c|c|c|c|}
\hline $\begin{array}{l}\text { patient } \\
\text { number }\end{array}$ & sex & $\begin{array}{l}\text { BMI } \\
{\left[\mathrm{kg} / \mathrm{m}^{2}\right]}\end{array}$ & $\begin{array}{l}\text { age } \\
\text { [years] }\end{array}$ & $\begin{array}{l}\text { duration } \\
\text { of symp- } \\
\text { toms }\end{array}$ & pain characteristics & $\begin{array}{l}\text { tenderness } \\
\text { to palpa- } \\
\text { tion in } \\
\text { sacral } \\
\text { region? }\end{array}$ & $\begin{array}{l}\text { neurological } \\
\text { deficits? }\end{array}$ & $\begin{array}{l}\text { prior spine } \\
\text { surgery }\end{array}$ & relevant diseases \\
\hline 1 & $f$ & 32.0 & 80 & $>6$ weeks & $\begin{array}{l}\text { intractable and immobiliz- } \\
\text { ing low back pain radiating } \\
\text { to the buttock and nonspe- } \\
\text { cifically to the proximal } \\
\text { lower limbs, exacerbation } \\
\text { at mobilization }\end{array}$ & Yes & none & none & $\begin{array}{l}\text { - osteoporosis } \\
\text { - obesity } \\
\text { - ventrolisthesis L3/4 (grade I) } \\
\text { - Parkinson's disease } \\
\text { - bilateral total knee replace- } \\
\text { ment }\end{array}$ \\
\hline 2 & $f$ & 38.5 & 64 & $\begin{array}{l}\text { several } \\
\text { months }\end{array}$ & $\begin{array}{l}\text { low back pain radiating to } \\
\text { both groins }\end{array}$ & Yes & none & $\begin{array}{l}\text { posterior } \\
\text { spondylod- } \\
\text { esis of L5/S1 } \\
\text { (minimally } \\
\text { invasive) }\end{array}$ & $\begin{array}{l}\text { - osteoporosis } \\
\text { - obesity } \\
\text { - bilateral total hip arthroplasty } \\
\text { - fibromyalgia } \\
\text { - diabetes mellitus } \\
\text { - depression }\end{array}$ \\
\hline 3 & $f$ & 31.9 & 81 & $\begin{array}{l}\text { several } \\
\text { months }\end{array}$ & $\begin{array}{l}\text { exacerbated low back pain } \\
\text { radiating nonspecifically to } \\
\text { the proximal lower limbs to } \\
\text { a lesser extent, pain in- } \\
\text { creasing at mobilization }\end{array}$ & Yes & none & none & $\begin{array}{l}\text { - osteoporosis } \\
\text { - obesity } \\
\text { - bilateral total knee replace- } \\
\text { ment }\end{array}$ \\
\hline 4 & $f$ & 21.6 & 69 & 2 months & $\begin{array}{l}\text { low back pain radiating } \\
\text { to both groins }\end{array}$ & Yes & $\begin{array}{l}\text { hypesthesia } \\
\text { in the left } L 5 \\
\text { dermatome }\end{array}$ & none & $\begin{array}{l}\text { - rheumatoid arthritis } \\
\text { - bilateral total hip arthroplasty } \\
\text { - right total knee replacement } \\
\text { - fibromyalgia } \\
\text { - breast cancer } \\
\text { - restless legs }\end{array}$ \\
\hline
\end{tabular}

$\mathrm{BMI}$ - body mass index
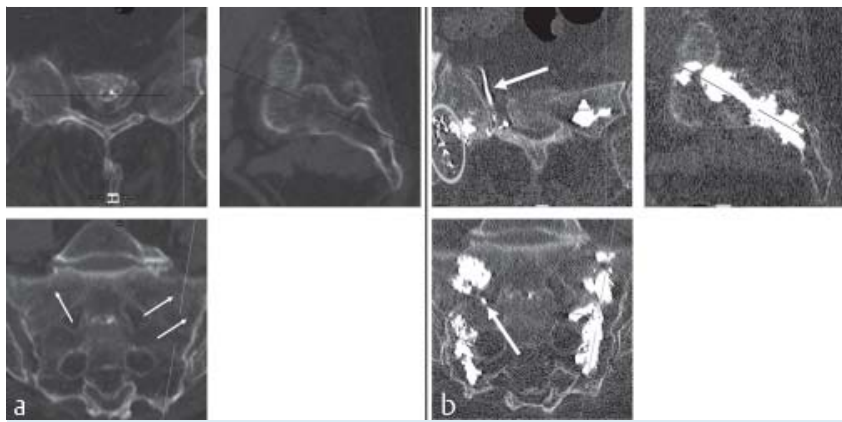

Fig. 6 Preoperative and postoperative imaging (Patient 3). a The preoperative triplanar CT scans show bilateral fracture lines (arrows) and wide osteopenic areas of the sacral alae. b The postoperative triplanar CT scan displays the distribution of bone cement with cement extravasation into a vein passing through the right neural foramen of S2 (arrows) and into the right sacroiliac joint (encircled) without being symptomatic.

Abb. 6 Präoperative und postoperative Bildgebung (Patient 3). a Das präoperative triplanare CT zeigt bilaterale Frakturlinien (Pfeile) und ausgedehnte osteopenische Gebiete der Alae ossis sacri. b Das postoperative triplanare CT zeigt die Knochenzementverteilung mit Zementextravasationen in eine Vene, die durch das rechte S2-Neuroforamen (Pfeile) zieht, sowie in das rechte lliosakralgelenk (eingekreist) ohne Anhalt für eine Schmerzverursachung.

$18-20,26,28-34]$. Conventional balloon kyphoplasty has been described for osteoporotic fractures [11, 20,31], metastatic fractures [20], and a sacral hemangioma [32] of the sacrum. However, literature data regarding sacroplasty consists mainly of retrospective reports with limited numbers $[11,16,18-20,26,28$ 35 ] and a prospective observational cohort study with 52 pa-
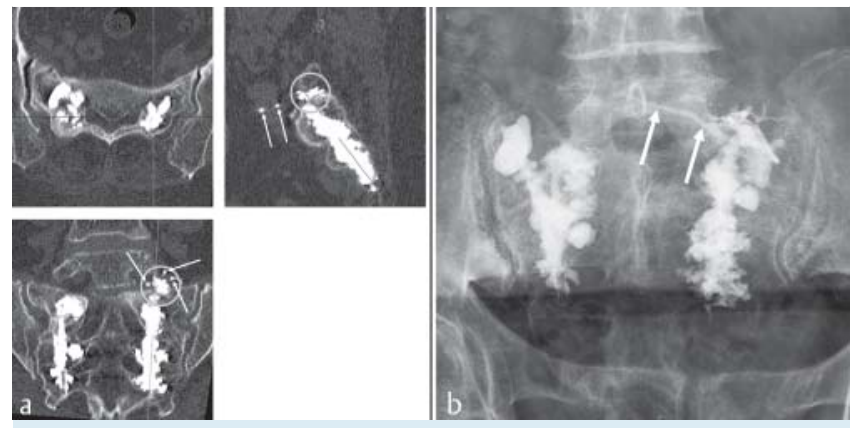

Fig. 7 Postoperative imaging (Patient 1). Postoperative triplanar CT scan a and anterior-posterior plain X-ray b show cement distribution into the targeted areas containing the bilateral sacral insufficiency fractures as well as the extensive osteopenic areas of the sacral alae. Imaging revealed cement extravasation through the superior margin of the sacral ala (encircled in a) as well as into a presacral vein (arrows in $\mathbf{a}, \mathbf{b}$ ). None of the cement extravasations was symptomatic.

Abb. 7 Postoperative Bildgebung (Patient 1). Das postoperative triplanare $\mathrm{CT}$ a und das anterior-posterior Röntgenbild $\mathbf{b}$ zeigen eine Zementverteilung in die Bereiche der bilateralen sakralen Insuffizienzfrakturen als auch der ausgedehnten osteopenischen Gebiete der Alae ossis sacri. Die Bildgebung weist ebenso Zementextravasationen im Bereich der Basis ossis sacri (eingekreist in a) sowie in eine präsakrale Vene (Pfeile in a, b) nach. Die Zementextravasationen waren ohne Anhalt für eine Schmerzverursachung.

tients [13]. Bayley et al. [7] summarized in their review that the average VAS score significantly improved from 8.9 preoperatively to 2.6 after conventional sacroplasty in 62 patients. Recently, the largest study to date by Kortman et al. [3] compiled 204 patients with SIFs in a retrospective multicenter analysis and confirmed the fast and durable pain relief from an average 


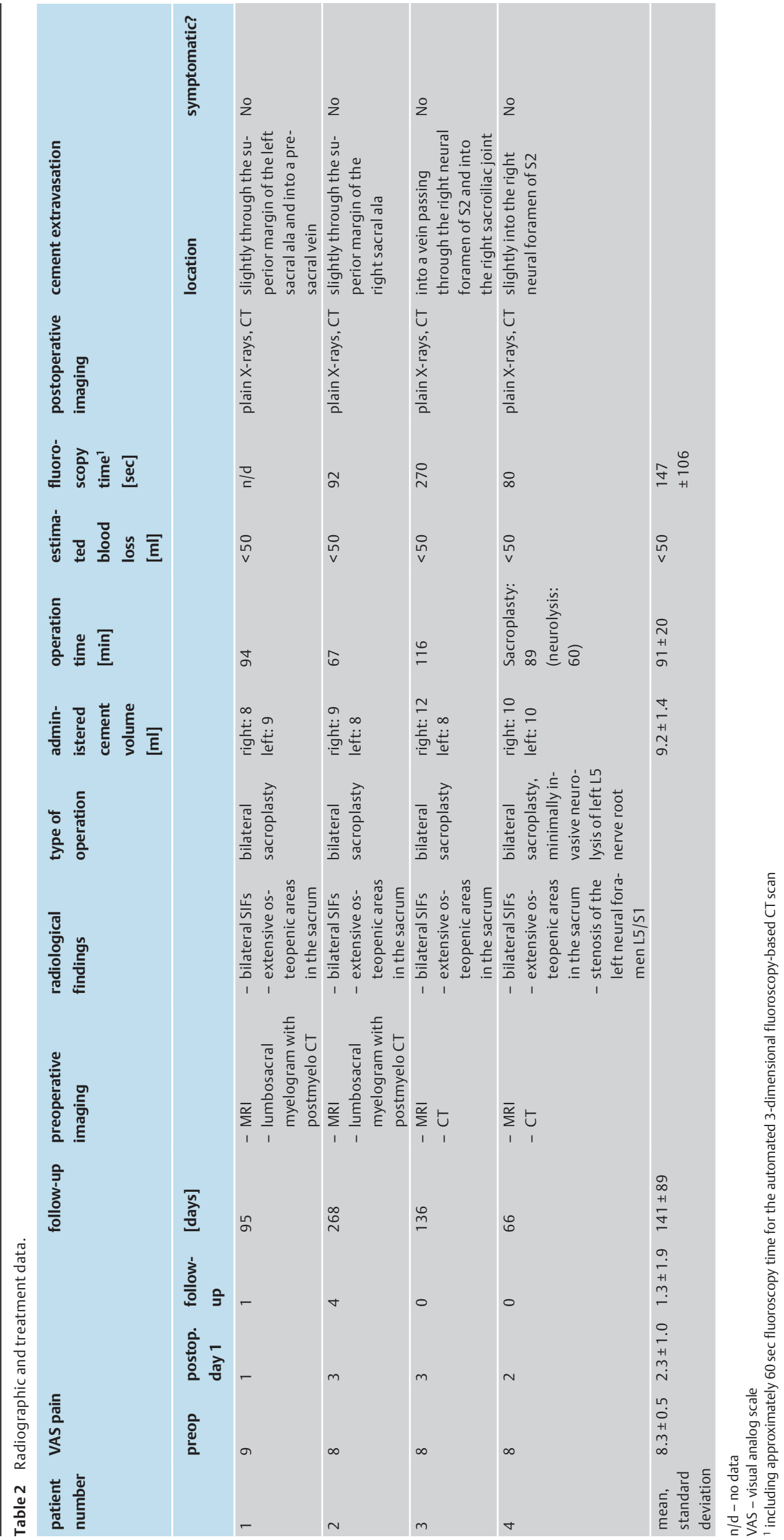


VAS score of $9.2 \pm 1.1$ to $1.9 \pm 1.7$ after sacroplasty. The pain reduction after sacroplasty with navigation-guided radiofrequency kyphoplasty in our study corresponds to these results.

\section{Cement extravasation}

Regardless of clinical improvement of treated patients, cement extravasation remains a major concern in augmentation techniques, especially in extensive SIFs demanding larger injection volumes of cement. Pommersheim et al. [12] discussed whether wide fracture lines may be a contraindication for using augmentation techniques solely. Furthermore, current bone cements offer a short working time of less than ten minutes [27], which may lead to rushing during the injection of bone cement in osteoporotic SIFs with widespread osteopenic areas.

Additionally, the capacious medullary cavity of the sacrum offers little resistance or feedback to the surgeon, unlike vertebral bodies during vertebroplasty $[12,31]$. Cement extravasation during sacroplasty into paraspinal soft tissues, sacroiliac joints, neural foramen, and intravenously was reported. The extravasations were mostly described as asymptomatic $[7,12,13,16,20,26$, $28,31,36]$. However, transient L5 radiculopathy [36] and transient $S 1$ radiculopathy $[13,20]$ occurred. The sacral spinal canal as another possible location for cement extravasation has not been reported yet. Unfortunately, the comprehensive study of Kortman et al. [3] did not address the issue of cement extravasations in detail. Asymptomatic cement extravasations were not mentioned at all. One symptomatic cement extravasation causing radicular pain required surgical decompression. A further patient experienced a progressive fracture dislocation one week after the procedure [3]. The present study meticulously examined cement extravasations in thin-sliced and triplanar reconstructed CT scans. Correspondingly, slight cement extravasations could be detected in each patient, which had not been observed fluoroscopically. None of these cement extravasations was symptomatic. Radiofrequency kyphoplasty combines the advantage of very high viscous bone cement with a considerably extended working time of approximately 30 minutes and has already shown encouraging results for the treatment of vertebral body fractures $[21,23,27]$.

From the limited experience with the presented patients, we affirm convenient and controlled cement delivery using radiofrequency kyphoplasty in SIFs. However, we observed slight cement extravasations into a presacral vein, into a vein passing through a neural foramen, into the sacroiliac joint and above the superior margin of the sacral ala in our patients after delivering an average of $9.2 \mathrm{ml}$ (range, $8-12 \mathrm{ml}$ ) of bone cement to each side (0 Fig. 3 , $5-7$ ), but these were not symptomatic. The amount of cement injected on each side in the literature varies between 2 and $10 \mathrm{ml}$ for the long-axis approach $[3,7]$.

\section{Intraoperative imaging, navigation guidance}

Sacroplasty imposes particular challenges on the surgeon since fluoroscopy insufficiently identifies anatomic landmarks in extensive osteopenic areas. Particularly lateral fluoroscopic visualization of the sacrum is very limited as a result of the pelvis and iliac bones $[3,29]$. Especially in the long-axis approach, penetration of the superior margin of the sacral ala is described as a potential risk $[7,26]$. Therefore, other authors agree that using a CTguided operation technique is essential for suitable orientation and controlled positioning of the bone needles in the sacrum [3, $28-30,34,35]$. To prevent misplacement of bone needles as well as major or symptomatic cement extravasations to the greatest extent possible, we consider the use of navigated bone needles as highly useful for controlled and accurate initial placement as well as possible movements of the needles during cement delivery ( $\bullet$ Fig. 3,4$)$. It is noteworthy that with the use of the navigation system no further fluoroscopy is necessary for repositioning the navigated bone needle preventing additional radiation exposure.

\section{Radiation exposure}

A hand switch permits remote cement delivery at a distance of three meters from the radiation source, thus reducing the radiation exposure for the surgeon $[23,27]$. Moreover, the radiation exposure for the operating room staff could be further reduced using the 3D fluoroscopy-based CT navigation because the staff is outside the operating room during the acquisition of the 3D scan. Thus, the mean time of radiation exposure for the operating room staff was $87 \pm 106 \mathrm{sec}$ (range, $20-210 \mathrm{sec}$ ) after the subtraction of $60 \mathrm{sec}$ for the intraoperative 3D fluoroscopy-based CT scan. Layton et al. [29] estimated an effective dose of $140 \mathrm{mSv}$ for sacroplasty in a case report using CT fluoroscopy guidance for placing 4 bone needles via a short axis approach and CT fluoroscopy for controlling cement injection. These data, however, are hardly comparable with the operation and imaging technique of the present study.

\section{Other aspects}

From an economic point of view, radiofrequency kyphoplasty may be cost-reductive. While several disposable kits of other augmentation systems may be needed for treating extensive SIFs, a single radiofrequency kyphoplasty disposable kit allows multiple intermittent deliveries at different sites ( $\boldsymbol{\bullet}$ Fig. $\mathbf{4} \mathbf{f}, \mathbf{g}$ ), which additionally reduces the procedural time. In the most comprehensive series to date, an average use of 2.5 bone needles for each procedure was reported with a range of $1-5$ [3]. In the present study, one bone needle was sufficient for each side without any difficulty.

\section{Conclusion \\ $\nabla$}

From the limited experience in four patients, navigation-guided radiofrequency kyphoplasty appears to be a safe and effective treatment for SIFs. The intraoperative 3D navigation facilitates a highly improved orientation in the sacrum and therefore safe placement of bone needles. The StabiliT ER ${ }^{2}$ bone cement warrants a very high viscosity and a prolonged working time. In our opinion, these features result in more convenient and controlled cement delivery and may be beneficial in regard to symptomatic cement extravasation even though asymptomatic cement extravasation occurred. Additional clinical studies with higher numbers and a longer follow-up period are necessary to compare radiofrequency kyphoplasty, conventional augmentation techniques and conservative treatment in SIFs.

\section{Abbreviation key \\ $\nabla$ \\ CT computed tomography \\ MRI magnetic resonance imaging \\ SIF sacral insufficiency fracture \\ VAS visual analog scale}




\section{References}

1 De Smet AA, Neff JR. Pubic and sacral insufficiency fractures: clinical course and radiologic findings. Am J Roentgenol Am J Roentgenol 1985; 145: $601-606$

2 Wild A, Jaeger M, Haak $H$ et al. Sacral insufficiency fracture, an unsuspected cause of low-back pain in elderly women. Arch Orthop Trauma Surg 2002; 122: 58-60

3 Kortman K, Ortiz O, Miller Tet al. Multicenter study to assess the efficacy and safety of sacroplasty in patients with osteoporotic sacral insufficiency fractures or pathologic sacral lesions. J Neurointerv Surg 2012, [Epub ahead of print]

4 Rawlings CE 3rd, Wilkins RH, Martinez S et al. Osteoporotic sacral fractures: a clinical study. Neurosurgery 1988; $22: 72-76$

5 Peh WC, Khong PL, Ho WY et al. Sacral insufficiency fractures. Spectrum of radiological features. Clin Imaging 1995; 19: 92 - 101

6 Lyders EM, Whitlow CT, Baker MD et al. Imaging and treatment of sacral insufficiency fractures. AJNR Am J Neuroradiol 2010; 31: 201 - 210

7 Bayley E, Srinivas S, Boszczyk BM. Clinical outcomes of sacroplasty in sacral insufficiency fractures: a review of the literature. Eur Spine J 2009; 18: 1266 - 1271

8 Gotis-Graham I, McGuigan L, Diamond T et al. Sacral insufficiency fractures in the elderly. J Bone Joint Surg Br 1994; 76: 882-886

9 Lourie H. Spontaneous osteoporotic fracture of the sacrum. An unrecognized syndrome of the elderly. JAMA 1982; 248: 715-717

10 Babayev M, Lachmann E, Nagler W. The controversy surrounding sacral insufficiency fractures: to ambulate or not to ambulate? Am J Phys Med Rehabil 2000; 79: 404-409

11 Andresen R, Radmer S, Kamusella P et al. Interventionelle Schmerztherapie mittels Ballon-Kyphoplastie bei Patienten mit osteoporosebedingten Insuffizienzfrakturen des Os sacrum. Fortschr Röntgenstr 2012; 184: $32-36$

12 Pommersheim W, Huang-Hellinger F, Baker M et al. Sacroplasty: a treatment for sacral insufficiency fractures. AJNR Am J Neuroradiol 2003; 24: $1003-1007$

13 Frey ME, DePalma MJ, Cifu DX et al. Percutaneous sacroplasty for osteoporotic sacral insufficiency fractures: a prospective, multicenter, observational pilot study. Spine J 2008; 8: 367-373

14 Frey ME, DePalma MJ, Cifu DX et al. Efficacy and safety of percutaneous sacroplasty for painful osteoporotic sacral insufficiency fractures: a prospective, multicenter trial. Spine 2007; 32: 1635-1640

15 Whitlow CT, Mussat-Whitlow BJ, Mattern CW et al. Sacroplasty versus vertebroplasty: comparable clinical outcomes for the treatment of fracture-related pain. AJNR Am J Neuroradiol 2007; 28: 1266-1270

16 Butler CL, Given CA 2nd, Michel SJ et al. Percutaneous sacroplasty for the treatment of sacral insufficiency fractures. Am J Roentgenol 2005; 184: $1956-1959$

17 Hess GM. Sakroplastie zur Behandlung von Insuffizienzfrakturen des Sakrums. Unfallchirurg 2006; 109: 681-686

18 Garant M. Sacroplasty: a new treatment for sacral insufficiency fracture. J Vasc Interv Radiol 2002; 13: 1265 - 1267
19 Trouvin AP, Alcaix D, Somon T et al. Analgesic effect of sacroplasty in osteoporotic sacral fractures: A study of six cases. Joint Bone Spine 2012; DOI: 10.1016/j.jbspin.2011.12.005 Epub 2012 Jan 27

20 Shah RV. Sacral kyphoplasty for the treatment of painful sacral insufficiency fractures and metastases. Spine J 2012; 12: 113-120

21 Bornemann R, Hanna M, Kabir $K$ et al. Continuing conservative care versus crossover to radiofrequency kyphoplasty: a comparative effectiveness study on the treatment of vertebral body fractures. Eur Spine J 2012; 21: 930-936

22 Bastian JD, Keel MJ, Heini PF et al. Complications related to cement leakage in sacroplasty. Acta Orthop Belg 2012; 78: 100-105

23 Elgeti FA, Marnitz T, Kroncke TJ et al. DFine Radiofrequenzkyphoplastie (RFK) - Kyphoplastie mit ultrahochviskösem Zement. Fortschr Röntgenstr 2010; 182: 803-805

24 Röllinghoff $M$, Zarghooni $K$, Zeh $A$ et al. Is there a stable vertebral height restoration with the new radiofrequency kyphoplasty? A clinical and radiological study. Eur J Orthop Surg Traumatol 2012, [Epub ahead of print]

25 Denis F, Davis S, Comfort T. Sacral fractures: an important problem. Retrospective analysis of 236 cases. Clin Orthop Relat Res 1988; 227: $67-81$

26 Smith DK, Dix JE. Percutaneous sacroplasty: long-axis injection technique. Am J Roentgenol Am J Roentgenol 2006; 186: 1252 - 1255

27 Robertson SC. Percutaneous vertebral augmentation: StabilitiT a new delivery system for vertebral fractures. Acta Neurochir Suppl 2011; 108: $191-195$

28 Heron J, Connell DA, James SL. CT-guided sacroplasty for the treatment of sacral insufficiency fractures. Clin Radiol 2007; 62: 1094-1103

29 Layton KF, Thielen KR, Wald JT. Percutaneous sacroplasty using CT fluoroscopy. AJNR Am J Neuroradiol 2006; 27: 356 -358

30 Strub WM, Hoffmann M, Ernst RJ et al. Sacroplasty by CT and fluoroscopic guidance: is the procedure right for your patient? AJNR Am J Neuroradiol 2007; 28: 38-41

31 Deen HG, Nottmeier EW. Balloon kyphoplasty for treatment of sacral insufficiency fractures. Report of three cases. Neurosurg Focus 2005; 18: e7

32 Atalay B, Caner H, Yilmaz C et al. Sacral kyphoplasty for relieving pain caused by sacral hemangioma. Spinal Cord 2006; 44: 196-199

33 Naderi S, Ilaslan H, Aslan A et al. Sacroplasty: report of three cases. Turk Neurosurg 2010; 20: 418-422

34 Kamel EM, Binaghi S, Guntern D et al. Outcome of long-axis percutaneous sacroplasty for the treatment of sacral insufficiency fractures. Eur Radiol 2009; 19: 3002-3007

35 Lüdtke CW, Kamusella P, Andresen R. Schmerzbehandlung bei pathologischer Os-sacrum-Fraktur mittels CT-gesteuerter Ballonsakroplastie. Fortschr Röntgenstr 2012; 184: 578-580

36 Choi KM, Song JH, Ahn SK et al. Therapeutic considerations of percutaneous sacroplasty for the sacral insufficiency fracture. J Korean Neurosurg Soc 2010; 47: $58-63$ 